\title{
Atypical territorial infarction in moyamoya disease
}

\author{
J.Y. Lee, MD; K.S. Kim, MD; S.K. Song, MD; S.H. Ahn, MD; H.S. Nam, MD; \\ and J.H. Heo, MD, PhD
}

A 71-year-old woman presented with sudden akinetic mutism. MRI showed an infarction on the anterior portion of the brain. Angiographic studies demonstrated occlusion of both internal carotid arteries at the supraclinoid portion and extensive collaterals (figure), which were suggestive of moyamoya disease. ${ }^{1}$ Although symptom onset at age 71 is unusual in moyamoya disease, underlying diseases that may be associated with moyamoya-like vasculopathies (moyamoya syndrome) were not found despite the extensive work-ups. An infarction involved only the anterior part of the anterior and middle cerebral artery territories, ${ }^{2}$ which indicated that distorted vascular territories in moyamoya disease caused an atypical territorial infarction.

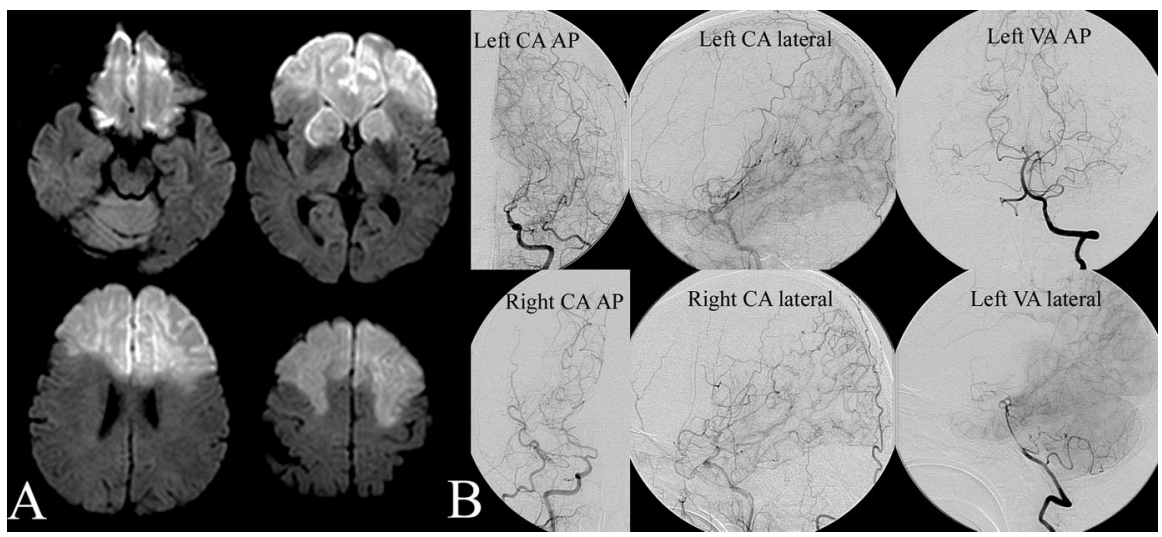

Figure. (A) Diffusion-weighted axial MRI shows an acute infarction involving the bilateral frontal lobes and anterior portions of the basal ganglia.

(B) Carotid (CA) and vertebral (VA) angiograms demonstrate occlusion of both internal carotid arteries and well developed bilateral leptomeningeal and basal collaterals from the posterior cerebral and external carotid arteries.

\section{References}

1. Fukui M. Guidelines for the diagnosis and treatment of spontaneous occlusion of the circle of Willis ("moyamoya" disease). Research Committee on Spontaneous Occlusion of the Circle of Willis (Moyamoya Disease) of the
Ministry of Health and Welfare, Japan. Clin Neurol Neurosurg 1997;99(Suppl 2): S238S240.

2. Tatu L, Moulin T, Bogousslavsky J, Duvernoy $\mathrm{H}$. Arterial territories of the human brain Cerebral hemispheres. Neurology 1998;50: 1699-1708.

From the Department of Neurology, National Core Research Center for Nanomedical Technology, Brain Korea 21 Project for Medical Sciences, Yonsei University College of Medicine, Seoul, Korea.

Supported by KOSEF through National Core Research Center for Nanomedical Technology (R15-2004-024-00000-0).

Disclosure: The authors report no conflicts of interest.

Received June 16, 2005. Accepted in final form August 3, 2005.

Address correspondence to Dr. Ji Hoe Heo, Department of Neurology, Yonsei University College of Medicine 134 Shinchon-dong, Seodaemoon-ku, 120-752, Seoul, Korea; e-mail: jhheo@yumc.yonsei.ac.kr 


\title{
Neurology
}

\author{
Atypical territorial infarction in moyamoya disease \\ J. Y. Lee, K. S. Kim, S. K. Song, et al. \\ Neurology 2005;65;E28 \\ DOI 10.1212/01.wnl.0000187130.03548.9f
}

This information is current as of December 27, 2005

\section{Updated Information \&} Services

References

Citations

Permissions \& Licensing

Reprints including high resolution figures, can be found at: http://n.neurology.org/content/65/12/E28.full

This article cites 1 articles, 1 of which you can access for free at: http://n.neurology.org/content/65/12/E28.full\#ref-list-1

This article has been cited by 1 HighWire-hosted articles: http://n.neurology.org/content/65/12/E28.full\#\#otherarticles

Information about reproducing this article in parts (figures,tables) or in its entirety can be found online at:

http://www.neurology.org/about/about_the_journal\#permissions

Information about ordering reprints can be found online:

http://n.neurology.org/subscribers/advertise

Neurology ${ }^{\circledR}$ is the official journal of the American Academy of Neurology. Published continuously since 1951, it is now a weekly with 48 issues per year. Copyright . All rights reserved. Print ISSN: 0028-3878. Online ISSN: 1526-632X.

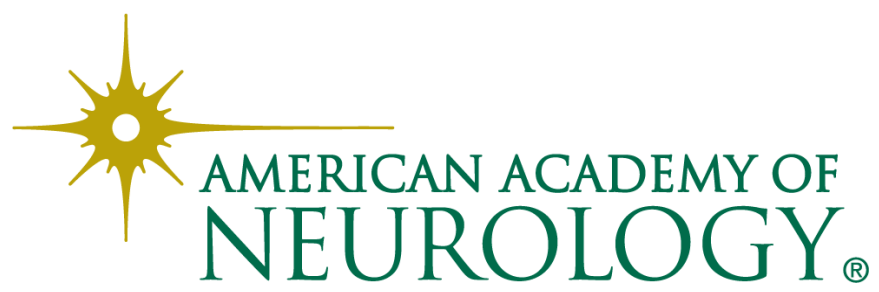

